\title{
Heroes and villains
}

SIR-Benno Müller-Hill is known not only as a specialist in molecular biology but also as someone involved in establishing the personal responsibility of scientists for inhuman experiments under the Nazis. In his review of Daniil Granin's book (Nature 336. 721; 1988) about Nicolai Timoféeff-Ressovsky under the heading "Heroes and Villians", he confirms that Timoféeff-Ressovsky did not participate in such experiments. At the same time, Müller-Hill implies that TimoféeffRessovsky, contrary to Granin's opinion, was not a heroic person, because, as head of the genetics department at Kaiser Wilhelm Institute, he had business contacts with proponents of 'racial hygiene'. (Müller-Hill later testifies that TimoféeffRessovsky did not himself publish a single anthropological paper.)

An objective look at the past together with a trustworthy evaluation of the personal conduct of those living under totalitarian regimes is very important. Timoféeff-Ressovsky is unique - he had to live and work both in Hitler's Germany and Stalin's Soviet Union.

In our opinion, in order properly to understand and evaluate the life and deeds of Timoféeff-Ressovsky, it is not sufficient to see them through the eyes of somebody living much later in a comfortable democratic society. For example, Pyotr Kapitsa, when rescuing the persecuted Lev Landau, wrote a letter to Stalin. Its content and especially its form seem unattractive by the moral standards accepted in Western democratic societies: in this letter, the prominent physicist humbly asks Stalin to release his guiltless colleague from prison and promises that Landau will not in future act against the state. But taking into account the situation in the Soviet Union at that time, this was an act of heroism by Kapitsa because it could have cost him his life.

Similarly, Timoféeff-Ressovsky's behaviour must be considered in the light of the society in which he lived. Specifically, the basic questions should be answered: What was Timoféeff-Ressovsky's credo? And did he follow it?

Timoféeff-Ressovsky was deeply religious. He believed in the absolute character of good and in the transient character of evil. He considered science a humanistic force, while believing that it was not able to answer the basic moral questions.

When he lived in Germany, he helped many people to hide at the risk of his own life. His voluntary return to the Soviet Union, about which he had thought deeply, almost cost him his life: he was persecuted for having been in Germany and nearly died from pellagra in Gulag.

We wish to stress that the division of people into "heroes and villians" is a direct consequence of existence under a totalitarian regime which (especially for active people) leaves almost no possibility of choice. Refusing to become a villian, Timoféeff-Ressovsky must have been a hero.

It was in the Soviet Union that Timoféeff-Ressovsky accomplished what was probably his most important achievement: the restoration of communication between different generations of biologists, which had been almost lost because of Lysenko.

According to the opinions of people who knew him well, Timoféeff-Ressovsky - the descendant of the princely Vsevolzhskies - never betrayed his ancestral motto: "Honour above all!"

\section{Institute of Technology} and Safety of Drugs,

Moscow,

USSR

Institute of Molecular Biology,

VALERY I. IVANOV

USSR Academy of Sciences,

Moscow 117984

USSR

\section{Youthful virtues}

SiR-In his recent Commentary article ${ }^{1}$, John Ashworth provided extremely useful data on the complex relationship between research and teaching in universities. As he points out, and as I have argued elsewhere ${ }^{23}$, the British government's rejection of the 'tiering' (separation) of research and teaching at the level of the institute may be countered by de facto forces. So it is important to examine closely what little data we have; I suggest that Ashworth's are open to an alternative interpretation.

Ashworth himself notes that, at the University of Salford, the faculty has obtained much increased research-grant support from a varicty of sources, which has led to there being more postgraduates able to assist in teaching and that these students now actually do a large amount of teaching.

Further, plausible results of this arrangement are that permanent members of faculty not only can do more research. but, because they are under less pressure from teaching, can do what teaching they do better. And because the postgraduates are young and energetic and motivated to prove themselves, the teaching they carry out is especially apposite and supportive: having recently progressed through the undergraduate ranks, they will be well aware of what their students are up against. So, ironically. Ashworth's data could well be taken to support the argument for the separation of research and teaching.

Fundamental questions remain to be answered. What is the amount and form of contact between the permanent research faculty and undergraduates, and between the postgraduate teachers and undergraduates? How (if at all) does the postgraduate involvement in research affect their teaching? The answers may tell us that youth, and recent familiarity with the needs of undergraduates, carry their own virtucs. If so, that implies a very different form of tiering.

T.G. WHISTON

Science Policy Research Unit

University of Sussex.

Brighton BN1 9RF, UK

1. Ashworth, J. Nature 337, 223--225 (1989)

2. Whiston, T.G. Restructuring and Selectivity in Academic Wcience (Science Policy Support Group Concept Pap. No. . London 1988)

3. Whiston. T.G. in PrOC. CEDAT-SRHE Conf. Research - The Future for HE (Manchester Polytechnic. 1988)

\section{Window boxes?}

SIR-The stimulating article by Inoue and Horikoshi (Nature 338, 264-266; 1989) to the effect that one may select organisms that can grow in concentrations of toluene substantially greater than those normally used to make them permeable and thereby to kill them. leads one to remark that while the mechanism of this resistance remains uncertain (although it must involve changes in outer membrane permeability), this type of ability may be quite widespread and certainly less novel than supposed. It is for instance a common laboratory observation that a 20 per cent $(w / v)$ solution of the detergent Triton X100 held on a window ledge will quite soon (2-4 weeks) acquire a substantial crop of green algae.

In the spirit of the age in which schoolchildren make high- $T_{\mathrm{c}}$ superconductors, this type of experiment would scem eminently suitable for more widespread adoption. especially in the light of the recent 'greening' of our politicians.

DOUglas B. KeLL

Department of Biological Sciences,

University College of Wales,

Aberystwyth, Dyfed SY23 3DA, UK.

\section{Free speech}

SIR-Mr Salman Rushdie's right of free expression to denounce the canon of Islam has been lauded in recent wecks throughout the Western world.

Could not a similar freedom of speech be accorded to scientists to express heterodox vicws, or even simply to state facts that go against orthodox theory?

School of Mathematics

N. C. WICKRAMASINGHE

University of Wales College of Cardiff,

Senghenydd Road,

Cardiff CF2 4AG, UK 